\title{
The Analysis of Locus of Control and Managerial Skills on the Competitiveness of Micro, Small and Medium Enterprises (MSMEs) in Pangkalpinang City
}

\author{
Hamsani $^{1, *}$, Dian Prihardini Wibawa ${ }^{1}$, Ayu Wulandari ${ }^{1}$ \\ ${ }^{1}$ Economy Faculty of Bangka Belitung University \\ *Corresponding author. Email: hamsani.babel@gmail.com
}

\begin{abstract}
The fact shows that Micro, Small and Medium Enterprises (MSMEs) play a very important role in economic growth, even MSMEs are the only micro institutions that have not been swayed by the monetary crisis that began in 1988 and until now. However, as one of the mainstay sectors of society, especially the middle to lower class economic community, the role of MSMEs is not yet maximal, so that they are not fully able to compete, even worse, many MSMEs are out of business or inactive. Many factors cause the inability of MSMEs to compete, among others, due to low innovation and competitiveness so that they are not able to win competition both in the national and international realms. The decrease in the number of MSMEs from active to inactive, because these MSMEs are less able to survive in the arena of increasingly fierce competition, so that the only MSMEs that survive are those that have creations and innovations in accordance with the needs of the community. MSMEs have a personality that is less trusting than their low managerial abilities. If the MSME actors have Internal Locus of Control and high managerial abilities, then the UMKM players will be more creative and innovative.
\end{abstract}

Keywords: MSMEs, LoCI, LoCE, Managerial Skills

\section{INTRODUCTION}

It is undeniable that at this time, the role of Micro, Small and Medium Enterprises (MSMEs) has a strategic role in Indonesia's economic development. It is proven that MSMEs have been able to have a direct impact on people's lives in lower sectors. There are at least 3 roles of UMKM which are very important in the life of the small community, namely: first, means of alleviating poverty. The high rate of employment by MSMEs means that MSMEs are able to absorb a lot of labor. This is evident from data belonging to the Ministry of Cooperatives and MSMEs in 2011. It is stated that more than 55.2 million units of UMKM are able to absorb around 101.7 million people. This figure increases to around 57.8 million MSME units with a total workforce of 114 million people. Second, means for leveling the economic level of the small people. MSMEs also have a very important role in the economic equality of society. Unlike large companies, MSMEs have locations in various places. Even in areas far from the reach of modernization developments. The existence of MSMEs in 34 provinces in Indonesia reduces the economic gap between the poor and the rich. In addition, the small community does not need to go to the city in droves to get a decent living, UMKM is one of the places to meet the needs of all people, including rural communities. Third, is a source of foreign exchange for the country. The fact is that, Indonesian MSMEs are already very advanced. Its market share is not only on a national scale, but also internationally. The Ministry of Cooperatives and SMEs in 2017 stated that the foreign exchange of MSMEs players was high. The figure reached IDR 88.45 billion. This figure has increased up to eight times compared to 2016 [1].

However, it is not easy for MSMEs to play and develop their roles in the Indonesian economy. There are many problems and obstacles for MSMEs in developing their roles. Some of the weaknesses faced by MSMEs in Indonesia include: low quality of Human Resources (HR) in managing MSMEs including managerial skills of MSME actors such as technical skills, human relations skills and conceptual skills to manage MSMEs in order to increase competitiveness. In addition, MSME managers also have low product innovation abilities, especially in mastery of technology, management, information and markets. Likewise, the belief in the ability of MSME players also has an impact on 
competitiveness. The attitude of being confident / or unsure of the self-efficacy of MSME actors shows an attitude of Locus of Control.

Likewise, MSMEs in the Province of Bangka Belitung Islands also experience several obstacles in developing their UMKM. These constraints are significant with the decreasing number of active MSMEs in the Bangka Belitung Islands Province. Data for 2018 shows that the number of MSMEs in the Province of Bangka Belitung Islands has decreased drastically, except for MSMEs in Bangka and South Bangka Regency which have increased which can reach tens of times.

Based on data from the Office of Cooperatives and the Province of Bangka Belitung Islands (2019), it shows that on average, MSMEs in the Bangka Belitung Islands Province have decreased in quantity by around $10.7 \%$. The decline in the number of MSMEs in the Bangka Belitung Islands Province was due to a drastic decrease in the MSMEs in South Bangka, which initially totaled 47,122 in 2018 to 4,444 in 2019. If there were no MSMEs in South Bangka, then all the MSMEs in the Bangka Belitung island province had increased. Only MSMEs that survive are those that have creations and innovation in accordance with the needs of society. 'Inability to create creation and innovation because it is suspected that the majority of UMKM players lack character Locuf of Internal Control, namely belief in one's own abilities and on struggling with all his might to try to face challenges and be brave to take risks. While the opponent is Locus of Control External, namely lack of confidence, low effort and less courage to take risks. This second type indicates a high dependence on other people thus lacking new ideas for innovation to win competition [2].

Based on the background that has been described, the formulation of the problem in this study is the Analysis Locus of Control and Managerial Skills on the Competitiveness of Micro, Small and Medium Enterprises (MSMEs) in Pangkalpinang City.

\section{LITERATURE REVIEW}

The Law of the Republic of Indonesia Number 20 of 2008 concerning Micro, Small and Medium Enterprises in CHAPTER 1 article 1 has outlined what is meant by UMKM. Micro-enterprises are productive businesses owned by individuals and / or individual business entities that meet the criteria, namely having a net asset of not more than IDR 50,000,000 (excluding land and buildings for business premises) or having annual sales proceeds of at most IDR 300,000,000.00. Whereas the definition of Small Business is an independent productive economic enterprise, which is carried out by an individual or a business entity that is not a subsidiary or branch of a company that is owned, controlled, or is a part, either directly or indirectly, of a Medium or Large Business that owns net assets of more than IDR 50,000,000.00 up to a maximum of IDR 500,000,000.00 (excluding land and buildings for business premises) or have annual sales proceeds of more than IDR $300,000,000.00$ up to a maximum of IDR 2,500,000,000.00 . Medium Business is a productive economic business that stands alone, which is carried out by an individual or business entity that is not a subsidiary or branch of a company that is owned, controlled, or part of, either directly or indirectly, with the total net assets or annual sales proceeds, namely having assets. net of more than IDR 500,000,000.00 up to a maximum of IDR 10,000,000,000.00 (excluding land and buildings for business premises) or having annual sales proceeds of more than IDR 2,500,000,000.00 up to a maximum of IDR 50,000,000. 000.00. [3]

Competitiveness is one of the criteria for success and achievement of a goal of increasing and income and economic growth of a region or country. Competitiveness is identified with the ability level of productivity, which is the ratio of the level of output resulting from the level of input used. The indicators used to measure competitiveness are the comparative advantage and competitive advantage approaches [4].

The framework of competitiveness is reflected in internal and external factors. Internal factors consist of (1) the expertise or educational level of workers, (2) the expertise of employers, (3) availability or access to capital, (4) good organizational and management systems, (5) availability or mastery of technology, (6) availability or control of information, and (7) availability or control /access to other inputs such as energy, raw materials, and others [5].

According to Spector defines locus of control as a general belief that individual success and failure are controlled by individual (internal) behavior, or perhaps, that achievement, failure and success are controlled by other forces such as opportunity, luck and fate (external) [6]. Locus of control orientation devided into two, namely, internal locus of control and external locus of control. Internal locus of control is an individual's belief that something that is obtained depends on himself and is able to control his own life. A personality who acts on his own abilities, decisions and efforts. Meanwhile, external locus of control is an individual's belief that something obtained is beyond the individual's ability. External locus of control believes that his life is influenced by other factors outside of himself. Individuals believe that their actions are controlled by fate, luck, other people or other forces outside of themselves [7]

\section{METHOD}

The research was conducted in Pangkalpinang City. The sample in this study was as many as 50 MSMEs and sampling was carried out using the purposive sampling method, namely the sampling technique with certain considerations [8].

The data analysis technique in this study used a qualitative and quantitative descriptive approach, both descriptive and inferential. In addition, to map the condition of the problems faced and to design an appropriate strategy, several appropriate analysis tools 
are used. Qualitative Descriptive Analysis is used to identify MSMEs based on the objective conditions of several types of businesses in Pangkalpinang City. Meanwhile, Quantitative Descriptive analysis, as the name implies, descriptive will only describe the state of a symptom that has been recorded through a measuring instrument and then processed according to its function [9]. The results of the processing are then presented in the form of numbers so as to provide an indication of which dimensions are the most dominant owned by MSME actors from LoC and to what extent these dimensions affect the competitiveness of MSME players in Pangkalpinang City. To provide a score for each dimension using the following conditions:

1. Likert scale score determination. This study uses a 4point Likert scale (very low, low, moderate, high).

2. Determination of the lowest and highest scores. Assessment of the lowest questionnaire results is 1 (one) and the highest score is 4 (four)

3. Determination of the distance (interval) between the lowest value and the highest value. To obtain the internal magnitude between the lowest and highest values, you can use the following formula:

$$
\text { Interval }=\frac{\text { Highest value }- \text { Lowest value }}{\text { Number of classifications }}
$$

We know that the highest value is 4 and the lowest is 1 , while the number of classifications is 4 (very low, low, moderate, high), so based on the formula above, the size of the interval is:

$$
\text { Interval }=(4-1) / 4=0.75
$$

4. Enter the interval into each classification. The result of entering the interval will look like this:

Table 1. Classification Based on Intervals

\begin{tabular}{|c|c|}
\hline Range Skor & Description \\
\hline $1,00-1,75$ & Very Low \\
\hline$>1,75-2,50$ & Low \\
\hline$>2,50-3,25$ & Sufficient \\
\hline$>3,25-4,00$ & High \\
\hline
\end{tabular}

The assessment provisions apply generally to all variables in this study. Meanwhile, to measure the condition of the competitiveness of MSMEs using the following assessment criteria:

Score 160-200: Excellent competitiveness;

Score 120-160: Good competitiveness;

Score 80 - 120: Sufficient competitiveness

Score 40 - 80: Lack of competitiveness

Score 0 -40: No competitiveness

\section{RESULT AND DISCUSSIONS}

\section{Condition of Competitiveness of MSMEs in Pangkalpinang City}

The competitiveness of MSMEs in this study can be seen from 4 components, namely: technical and production skills, managerial skills, governance and service abilities and entrepreneurial skills [10]. By using 50 (fifty) respondents consisting of Pangkalpinang City UMKM players, the following descriptions are produced:

Table 2. Results of the Recapitulation of the Competitiveness of MSMEs in Pangkalpinang City

\begin{tabular}{|l|c|l|}
\hline \multicolumn{1}{|c|}{ Indicator UMKM } & Score & \multicolumn{1}{|c|}{ Description } \\
\hline $\begin{array}{l}\text { Engineering and production } \\
\text { capabilities }\end{array}$ & 118 & $\begin{array}{l}\text { Sufficient } \\
\text { competitiveness }\end{array}$ \\
\hline Managerial skills & 110 & $\begin{array}{l}\text { Sufficient } \\
\text { competitiveness }\end{array}$ \\
\hline $\begin{array}{l}\text { Governance and service } \\
\text { capabilities }\end{array}$ & 119 & $\begin{array}{l}\text { Sufficient } \\
\text { competitiveness }\end{array}$ \\
\hline $\begin{array}{l}\text { Entrepreneurial skills } \\
\text { Average score of } \\
\text { competitiveness }\end{array}$ & 122 & $\begin{array}{l}\text { Good } \\
\text { competitiveness }\end{array}$ \\
\hline
\end{tabular}

Source: Primary data, processed in 2020

From table 2 it can be seen that the condition of MSMEs in Pangkalpinang City is seen from 4 aspects, then the three aspects (technical and production capabilities, managerial abilities, governance and service capabilities) are in a condition of "adequate" competitiveness, but for the entrepreneurial aspect, Pangkalpinang City MSMEs are The condition is a little encouraging, namely the criteria for "good" dsing power. In general, from the four indicators, the condition of the competitiveness of MSMEs in Pangkalpinag City is still in the category of "adequate" competitiveness (score: 117.25).

It takes various efforts to raise the competitiveness ranking of MSMEs to a higher level, namely "very good" competitiveness (score 160-200). Improving input, production processes, maintaining output and production supporting factors is very important to maintain product quality and in turn will increase competitiveness, at least improve the competitiveness ranking, from increased "enough" competitiveness to "good" or even the "very good" competitiveness. It is necessary to select quality raw materials, increase the expertise and managerial skills of MSME managers must continue to be a concern so that MSMEs are able to compete.

\section{MSME Locus of Control (LoC) Condition in Pangkalpinang City}

Locus of Control is a description of an individual's beliefs about the determinants of their behavior. In other words, the type of LoC has an impact on a person's behavior. LoC is divided into 2, namely Internal Locus 
Of Control (ILoC) and External Locus of Control (EloC). Following are the results of LoC research on MSME actors in Pangkalpinang City.

Table 3. LoC Conditions for MSME Players in Pangkalpinang City

\begin{tabular}{|c|c|c|}
\hline Type of LoC & Score & Description \\
\hline IloC & 2,80 & high enough \\
\hline EloC & 2,49 & low \\
\hline
\end{tabular}

Source: Primary data, processed in 2020

From the table above, the ILoC type shows the number 2.80 is in the "high enough" category while the "low" category is for EloC. Because this study aims to find out which type of LoC is the most dominant for Pangkalpinang City MSMEs, and from the table above shows the ILoC value of 2.80 while the EloC value is 2.49 (ILoC> ELoC). Thus, MSME actors in Pangkalpinang City generally have ILoC behavior which is indicated by having high confidence in self-efficacy, being diligent, tenacious, working hard, trying to be independent, and continuing to improve their abilities and expertise. In addition, the ILoC-type UMKM entrepreneurs do not give up easily and never give up. This is the main asset in doing business, apart from being smart but also having to have a high fighting character and never stop to keep improving oneself.

\section{MSMEs Managerial Skills Conditions In Pangkalpinang City}

Managerial skills consist of conceptual abilities, human relationship skills and technical abilities. The following table describes the conditions of the three managerial skills of MSME actors in Pangkalpinang City.

Table 4. Recapitulation of managerial abilities of MSME actors in Pangkalpinang City

\begin{tabular}{|l|c|l|}
\hline \multicolumn{1}{|c|}{ Managerial Skills } & Score & \multicolumn{1}{|c|}{ Description } \\
\hline Conceptual ability & 3,15 & High enough \\
\hline Human relationship & 2,59 & High enough \\
\hline Technical ability & 2,23 & Low \\
\hline
\end{tabular}

Source: Primary data, processed in 2020

The table above shows that of the three managerial skills, conceptual skills have a higher score when compared to 25 other skills. While technical skills scored the lowest, human relations skills scored moderate between conceptual skills and technical skills.

\section{Effect of Locus of Control (LoC) on the Competitiveness of MSMEs}

As previously stated, LoC is a factor that influences a person's behavior. Everyone has both LoC characteristics, namely internal (ILoC) and external (ELoC), one of the two types is more dominant in a person so that it is stronger in influencing a person's behavior than the other types. The following table shows the influence of the two types of LoC on the competitiveness of MSME players in Pangkalpinang City.

Table 5. Effect of ILoc and ELoC on Competitiveness of MSMEs in Pangkalpinang City

\begin{tabular}{|c|r|r|r|r|r|}
\hline Model & \multicolumn{2}{|c|}{$\begin{array}{c}\text { Unstandardized } \\
\text { Coefficients }\end{array}$} & $\begin{array}{r}\text { Standardized } \\
\text { Coefficients }\end{array}$ & \multicolumn{1}{|c|}{ Sig. } \\
\cline { 2 - 4 } & \multicolumn{1}{|c|}{ B } & Std. Error & Beta & & \\
\hline (Constant) & 9,139 & 1,208 & & 7,566 & 0,000 \\
ILoC & 0,504 & 0,292 & 0,321 & 1,925 & 0,041 \\
\hline ELoC & 0,114 & 0,271 & 0,078 &, 420 & 0,677 \\
\hline
\end{tabular}

Source: Primary data, processed in 2020

Based on table 5, we can see that internal LoC has a positive and significant effect on the competitiveness of MSMEs in Pangkalpinang City, because it has a significant value below 5\%, which is only 0.041 . The positive influence between ILoC on competitiveness shows that if you are more confident, diligent, active, diligent, independent, do not give up easily and continue to develop abilities, these things will increase the competitiveness of MSME players in Pangkalpinang City, as well as on the other hand, an attitude of being lazy to try, giving up easily, and not wanting to develop skills and expertise will reduce the competitiveness of MSME players in Pangkalpinang City. As other evidence that shows a significant influence between ILoC on competitiveness, it can be seen by comparing the t-table value with the $\mathrm{t}$-count. If $\mathrm{t}$-count $>\mathrm{t}$-table, then $\mathrm{Ha}$ is accepted and Ho is rejected. With reference to the t-table, the magnitude t-table (taking into account $\mathrm{df}$ ) is 1.677 while the t-count for ILoC based on the table above is 1.925. T-count $>\mathrm{t}$-table, then the hypothesis which states that the Internal Locus of Control has a positive and significant effect on the competitiveness of MSMEs in Pangkalpinang City can be accepted. This is in line with the research conducted by Sudarsono and Irawati which states that there is a strong relationship between ILoC and the achievement of MSMEs [11]. Likewise, research conducted by Purnomo Lestari states that LoC has a positive and significant effect on the progress of MSMEs [12].

However, External Locus of Control (ELoC) has no significant effect on the competitiveness of MSMEs in Pangkalpinang City. However, simultaneously, both IloC and EloC have a positive and significant effect on the competitiveness of Pangkalpinang MSMEs players, this can be seen from the results of the Anova below. 
Table 6. LoC simultaneous test results on the Competitiveness of MSMEs in Pangkalpinang City

\begin{tabular}{|l|r|r|r|r|r|}
\hline \multicolumn{1}{|c|}{ Model } & $\begin{array}{r}\text { Sum of } \\
\text { Squares }\end{array}$ & Df & $\begin{array}{c}\text { Mean } \\
\text { Square }\end{array}$ & F & Sig. \\
\hline Regression & 17,050 & 2 & 8,525 & 3,953 &, $026^{b}$ \\
Residual & 101,370 & 47 & 2,157 & & \\
Total & 118,420 & 49 & & & \\
\hline
\end{tabular}

Source: Primary data, processed in 2020

Table 6 shows that the joint influence between ILoC and ELoC has a positive and significant effect, this illustrates that how an MSME business actor translates himself into business motivation, work attitudes, ethics, morals, commitment and business ability as well as the strength of his independence. against its competitiveness

\section{Effect of Managerial Skills on the Competitiveness of MSMEs}

The following table shows the regression results between managerial ability and competitiveness.

Table7. The results of the regression test of managerial ability on the competitiveness of MSMEs

\begin{tabular}{|l|r|r|r|r|c|}
\hline \multicolumn{1}{|c|}{ Model } & \multicolumn{2}{|c|}{$\begin{array}{c}\text { Unstandardized } \\
\text { Coefficients }\end{array}$} & $\begin{array}{c}\text { Stand. } \\
\text { Coefficients }\end{array}$ & T & Sig. \\
\cline { 2 - 4 } & $\mathbf{B}$ & $\begin{array}{c}\text { Std. } \\
\text { Error }\end{array}$ & Beta & & \\
\hline (Constant) & 6,916 & 1,782 & & 3,882 & 0,000 \\
$\begin{array}{l}\text { Conceptual } \\
\text { ability }\end{array}$ & 0,188 & 0,167 & 0,183 & 1,120 & 0,047 \\
$\begin{array}{l}\text { Human ability } \\
\text { Technical }\end{array}$ & 0,446 & 0,170 & 0,409 & 2,629 & 0,012 \\
ability & 0,116 & 0,140 & 0,110 & 0,827 & 0,412 \\
\hline
\end{tabular}

Source: Primary data, processed in 2020

Table 7: The results of the managerial ability regression test on the competitiveness of MSMEs in Pangkalpinang City. If we describe the managerial ability variable based on its dimensions, the table above shows that all dimensions of the managerial ability variable have a positive and significant effect (probability $<0.05$ ) on competitiveness, except for the technical ability dimension which has a positive but insignificant effect on the competitiveness of actors. UMKM Pangkalpinang City (probability> 0.05). Conceptual abilities include understanding the concept of cooperation, the relationship between employees, institutions and stakeholders as well as understanding technological developments, especially in anticipating any external changes that can affect the MSME structure. Because the effect of conceptual ability on the competitiveness of MSMEs in Pangkalpinang City is positive, understanding the concepts of cooperation with various external parties, technology concepts, concepts of change and other relevant concepts will increase the competitiveness of MSME players in Pangkalpinang City as well as On the other hand, if MSME actors do not understand the importance of cooperation and partners, are weak in the technology sector and do not care about changes, it will reduce their competitiveness. This is in line with the opinion of Cahyono and Suhada that managerial ability has a positive effect on the performance of MSMEs [13]. Likewise, the ability of human relationships which is reflected in the ability to interact with organizational members, cooperate, motivate, respect, respect and need each other will increase the competitiveness of Pangkalpinang City MSMEs. The probability value $<0.05$ is only 0.012 . The coefficient value of 0.446 indicates a positive relationship so that the more active interaction with employees, partners and stakeholders will increase competitiveness and vice versa. However, the third dimension of managerial ability is technical ability, for the level of MSME actors in this case the owners (MSME managers) do not have a significant effect on competitiveness (probability value> 0.04 which is equal to 0.412 but still has a positive relationship. This means that technical ability MSME actors such as technical ability to make reports, use a tool / machine and so on have less impact on competitiveness, because this job is a staff / operational task. Anova analysis shows that simultaneously managerial ability has a positive and significant impact on capability competitiveness of Pangkalpinang City MSMEs, thus H2 was declared accepted.

\section{Determination Test $\left(\boldsymbol{R}^{2}\right)$}

The determination test shows how much the ability of the independent variable (LoC) to predict competitiveness.

Table 7. The Determination Test

\begin{tabular}{|c|r|r|r|}
\hline $\mathrm{R}$ & $\mathrm{R}$ Square & $\begin{array}{c}\text { Adjusted } \mathrm{R} \\
\text { Square }\end{array}$ & $\begin{array}{c}\text { Std. Error of } \\
\text { the Estimate }\end{array}$ \\
\hline $0,595^{\mathrm{a}}$ & 0,455 & 0,419 & 1,45930 \\
\hline
\end{tabular}

Source: Primary data, processed in 2020

Table 7 shows that the independent variable is able to predict $41.9 \%$ of the competitiveness of SMEs in Pangkalpinang City, and the remaining $58.1 \%$ is influenced by other variables outside of this study.

\section{CONCLUSION}

Based on the discussion in the previous chapter, it can be concluded that Locus of Control and Managerial Skills have a positive and significant effect on the competitiveness of MSMEs players in Pangkalpinang City. For Locus of Control variable, Internal Locus of Contral (ILoC) is higher than External Locus of Control (ELoC). As for the managerial skills variable, the human relations ability of Pangkalpinang MSMEs actors is stronger than the conceptual and technical abilities. 


\section{ACKNOWLEDGMENTS}

In writing this paper the authors also thank the parties who have helped in the preparation of this paper either directly or indirectly for the sake of perfection substantially. The institution of Bangka Belitung University (UBB) one of the few parties that have been very helpful for the smooth writing of this paper.

\section{REFERENCES}

[1] Ministry of Cooperatives and SMEs, 2017.

[2] The Office of Cooperatives and the Province of Bangka Belitung Islands. 2019

[3] The Law of the Republic of Indonesia Number 20 of 2008 concerning Micro, Small, and Medium Enterprises

[4] Tarigan Robinson. Regional Economics: Theory and Applications. Jakarta: Bumi Aksara. 2005.

[5] Tambunan, T. T. H. Measures of Competitiveness of Cooperatives and SMEs. Planning Agency. 2008.

[6] Karimi, R dan Alipour, F. Reduce Job Stress in Organization: Role of Locus of Control, International Journal of Business and Social Science. Vol. 2 No. 18. pp. 231-236. 2011.

[7] Holt, D. T., Armenakis, A. A., Feild, H. S., \& Harris S. G. Readiness for organizational change; The systematic development of a scale, The Journal of Applied BehavioralScience 43(2), 232-255. 2007. doi: $10.1177 / 0021886306295295$

[8] Sugiyono. Qualitative and Combined Quantitative Research Methods (Mixed Methods). Bandung: Alfabeta. 2016.

[9] Ghozali, Imam. Multivariete Analysis Application with IBM SPSS 23 Program (8th Edition). VIII printing. Semarang: Diponegoro University Publishing Agency. 2016.

[10] Lantu, D. C., Triady, M. S., Utami, A. F., \& Ghazali, A. Development of models for increasing the competitiveness of MSMEs in Indonesia: Validation of quantitative models. The Asian Journal of Technology Management, 15(1), 77 . 2016.

[11] Sudarsono, B., \& Irawati, S. A. The Influence Of Internal And External Locus Of Control On The Achievement Of Middle Micro Businesses In Sampang District. EcoEntrepreneur, 2 (1), 120-131. 2016.

.[12] Purnomo, Sri Lestari. The Influence of Personality, Self-Efficacy, and Locus of Control on Perceptions of Small and Medium Scale Business Performance, Journal of Business and Economics (JBE), September, Vol. 17 No.2, pp. 144 -160, 2010.

[13] Cahyono, K. C. K., \& Suhada, B. S. B. The Effect of Credit Provision, Managerial Capability and
Product Differentiation on Umkm Performance in Metro City. DERIVATIVE: Journal of Management, 10(1). 2016. 